\title{
Antibacterial Screening of Bacterial Isolates Associated with Mangrove Soil from the Ngurah Rai Mangrove Forest Bali
}

\author{
Anak Agung Gede Indraningrat ${ }^{1}$, Made Dharmesti Wijaya ${ }^{2 *}$, Putu Arya Suryanditha ${ }^{1}$, \\ Ayu Savitri Siskayani ${ }^{3}$, Ni Made Defy Janurianti ${ }^{4}$ \\ ${ }^{1}$ Microbiology and Parasitology Department; ${ }^{2}$ Pharmacology and Pharmacy Department; ${ }^{3}$ Laboratory of Biomedical Science \\ Faculty of Medicine and Health Sciences, ${ }^{4}$ Faculty of Agriculture, Warmadewa University \\ Jl. Terompong No 24 Denpasar 80235, Tel. +62 361 240727, Indonesia.
}

Corresponding author*

dharmestiwijaya@gmail.com

Manuscript received: 20 October 2021. Revision accepted: 30 October, 2021. Published: 02 November, 2021.

\begin{abstract}
In this study we reported cultivation of bacteria associated with mangrove soil from the Ngurah Rai Mangrove Forest, Bali. Mangrove soil samples were serially diluted using sterile artificial seawater, spread onto Starch Casein M agar and incubated at $28^{\circ} \mathrm{C}$ for 28 days. Cultivation of mangrove soil samples yielded 165 bacterial colonies with 68 isolates were selected and purified based on different morphology. Of these 68 isolates, 22 isolates displayed antibacterial activities ranging from weak to strong inhibition against at least one of four bacterial indicators namely Staphyloccocus aureus, Streptococus mutans, Escherichia coli and Klebsiella pneumoniae using perpendicular streak method. Overall, 19 out of 22 bacteria isolates displayed weak antibacterial potential and two isolates exhibited moderate antibacterial activity. The isolate SA4 was the only bacterium with strong antibacterial potential with measured clear distance $\geq$ $10 \mathrm{~mm}$ against the four bacterial isolates. Sequence analysis based on 16S rRNA gene fragment assigned the isolate SA4 as Bacillus subtilis strain BIL/BS-168. Overall, this study confirmed the untapped potential of antibacterial activities from bacteria associated with mangrove soil.
\end{abstract}

Keywords: mangrove soil; bacteria; antibacterial screening.

\section{INTRODUCTION}

Bacterial resistance against antibiotic drugs is currently an emerging global health threat that require immediate actions (World Health Organization, 2018; Centers for Disease Control and Prevention, 2018). Antibiotic resistance arises because bacteria develop immune mechanism by mutation, horizontal gene transfer and enzyme inactivation (Munita and Arias, 2016). As a rough estimation, resistance against antibiotics will reach 10 millions cases in 2050 and is predicted to result in financial loss of 100 trillions USD due to increased cost for hospitalization and loss of productivity. To date, overused and misused antibiotics are the main factors of the increasing rate of antibiotic resistance (Ventola, 2015).

One of the efforts to overcome the increasing rate of resistance of pathogenic bacteria is to discover new sources of novel antibiotics with much stronger efficacy compared to current drugs that are available on the market (Roca et al., 2015; Cheng et al., 2016). Exploration of bacteria with a potent antibacterial activity has been mainly focused on terrestrial ecosystem (Elbendary et al., 2018; Singh et al., 2016; Mohamed et al., 2017; Assis et al., 2014). However, a number of studies indicated the highest de-replication of active compounds that have been previously reported. (Debbab et al., 2010). Therefore, exploration of marine habitat should also be given more priority as bacteria in this habitat is rather unexplored yet yield (Debbab et al., 2010).

Mangrove forest is characterized with extreme salinity, high-low tide, wind pressure, muddy and low oxygen concentratio (Friess, 2016). Therefore, microbe in this habitat tend to be able to adapt on harsh environmental conditions (Booth, 2018). The group of actinobacteria in mangrove forest synthesize various of secondary metabolites to survive with this extreme condition (van der Heul et al., 2018; Bentley et al., 2002). Bioactive compounds from mangrove origins have been shown to display therapeutics potential and could be developed as new drugs including antibiotics. A number of studies have isolated bacteria from mangrove and these isolates could inhibit wide range of pathogenic bacteria (Azman et al., 2015; Lee et al., 2014; Jiang et al., 2018).

The Ngurah Rai mangrove forest is the biggest mangrove ecosystem in Bali with over 19 mangrove plants species inhabited the area and dominated by four main species namely: Rhizophora mucronata, Avicennia 
marina, Rhizophora apiculata dan Sonneratia alba (Balai Pemantapan Kawasan Hutan Wilayah VIII Denpasar, 2018). To date diversity of bacteria in The Ngurah Rai Mangrove Forest is rather unexplored, therefore this research aims to isolate and pre-screen bacterial isolates with antibacterial activities.

\section{MATERIALS AND METHODS}

\section{Mangrove soil sampling}

Mangrove soil samples were collected from the Ngurah Rai Mangrove Forest (8'43'40.4886" S, 115'11'42.80313" E), in August 2019 during the low tide. Four sediment samples were taken from habitat of the four dominant mangrove plants Rhizophora mucronata, Avicennia marina, Rhizophora apiculata and Sonneratia alba. From each sampling point, approximately 100-gram sediment was taken from 10 $\mathrm{cm}$ depth using a clean masonry trowel and stored individually in a sterile $50 \mathrm{~mL}$ falcon tube (Figure 1). Soil samples were stored in $4^{\circ} \mathrm{C}$ until further used.

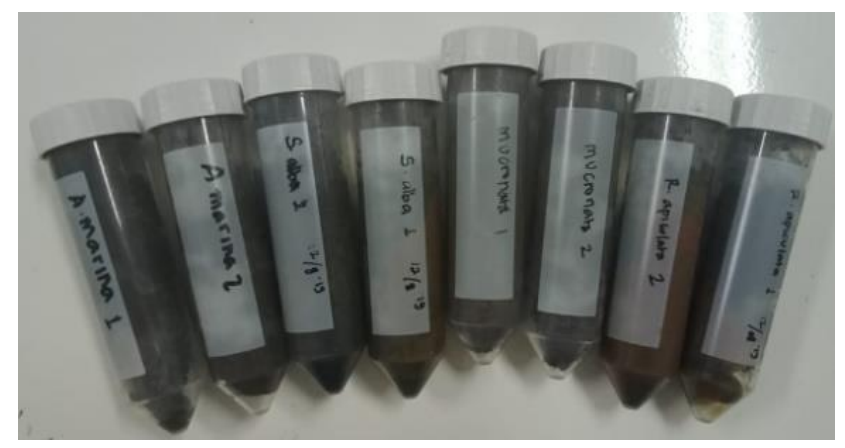

Figure 1. Soil samples collected from the Ngurah Rai Mangrove Forest.

\section{Cultivation of bacterial isolates from mangrove soils}

Ten grams of each mangrove soil samples were pretreated with wet heating in a water bath at $60^{\circ} \mathrm{C}$ for 15 minutes by combining sterile artificial seawater and distilled water (1:1 v/v) (Azman et al., 2015; Lee et al., 2014; Jiang et al., 2018). Subsequently, $1 \mathrm{~mL}$ of each of soil sample suspension was serially diluted $\left(10^{-1}\right.$ to $\left.10^{-3}\right)$ in $9 \mathrm{~mL}$ sterile artificial seawater. One hundred $\mu \mathrm{L}$ of each diluted soil sample was spread using sterile cotton swab (Onemedia) onto starch M-protein agar (63 gram/L, HiMedia, India) which was supplemented with $100 \mu \mathrm{g} / \mathrm{mL}$ nalidixic acid and $25 \mu \mathrm{g} / \mathrm{mL}$ nystatin. Agar plates were sealed with parafilm and incubated at $28^{\circ} \mathrm{C}$ for 28 days. Observation of colonies grew on agar was performed every two days and the total colonies observed on agar media were counted. Bacterial colonies with different morphologies (colour, form, elevation) were picked up from each agar plate and these colonies purified individually by streaked onto ISP-2 agar media (4.0 gram/L yeast extract, 10 gram/L malt extract, 4 gram/L dextrose, 20 gram/L bacto agar). Each of the purified bacterial isolate was stained using Gram staining dan observed under microscope to identify their morphological form.

\section{Antibacterial prescreening}

Antibacterial activities of each purified isolates were pre-screened using perpendicular streak method (Boontanom and Chantasari, 2020) with a slight modification against four bacterial indicator strains which represented Gram-negative bacteria (Escherichia coli dan Klebsiella pneumoniae) and Gram-positive bacteria (Staphylococcus aureus dan Streptococcus mutans). In brief, each of pure bacterial indicator strains was streaked as a five $\mathrm{cm}$ vertical line and incubated for 48 hours at $37^{\circ} \mathrm{C}$ until fully grown. Bacterial indicator strains were streaked five $\mathrm{cm}$ perpendicular from the original line of the bacterial isolate (Figure 2). Antibacterial potential was determined based on the distance formed between an isolate and a bacterial indicator according to four categories: no activity (a bacterial indicator show no distance with an isolate), weak $(1-4 \mathrm{~mm})$, moderate $(5-9 \mathrm{~mm})$ and strong $\geq 10$ $\mathrm{mm}$.

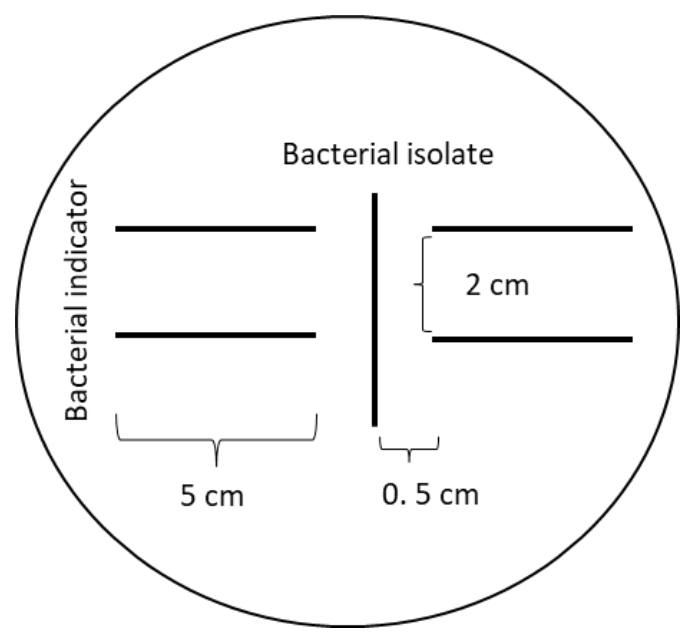

Figure 2. Schematic overview of perpendicular streak for antibacterial pre-screening of bacterial isolates from mangrove soil.

\section{Genetic analysis of bacterial isolates with strong} antibacterial activities

Bacterial isolates with a strong antibacterial activity were genetically identified using polymerase chain reactions followed by Sanger sequencing. The genomic DNA of selected bacterial isolates was extracted using Bacteria DNA preparation kit Jena Bioscience (Jena, Germany) by following the manufacturer instruction. Genomic DNA of each the selected isolates were amplified by targeting 16S rRNA gene fragment using primer pairs 27F: 5'-AGAGTTTGATCMTGGCTCAG3 ' and 1492R 5'-GGTTACSTTGTTACGACTT- 
3'(Lane, 1991). The $50 \mu \mathrm{L}$ PCR master mix contained $25 \mu \mathrm{L}$ My Taq HS Red Mix 2 x, $1 \mu \mathrm{L}(20 \mu \mathrm{M})$ of each forward and reverse primer, $22 \mu \mathrm{L}$ of sterile DNA/RNA free water and $1 \mu \mathrm{L}$ of genomic DNA. The PCR cycles consisted of $95^{\circ} \mathrm{C}$ for 5 minutes pre-denaturation, 30 cycles consisted of $95^{\circ} \mathrm{C}$ for $1 \mathrm{~min}$ denaturation, $55^{\circ} \mathrm{C}$ for 1 minutes annealing, $72^{\circ} \mathrm{C}$ for $1.5 \mathrm{~min}$ extension, and a final extension for 7 minutes. Amplified PCR product was analysed using $1 \%$ agarose supplemented with SYBR Safe by gel electrophoresis for 45 minutes $(80$ volt/200 watt) and visualised using UV light in a gel documentation machine. Subsequently, PCR products were sent to PT Genetika Science (https://ptgenetika.com/) for Sanger sequencing. The obtained sequence data were subjected to NCBI BLAST database (https://blast.ncbi.nlm.nih.gov/Blast.cgi) to assign the closely identity of related bacterial sequence.

\section{RESULTS AND DISCUSSION}

\section{Bacterial isolates with antibacterial activities}

A total of 68 bacterial isolates were selected over 165 bacterial colonies observed on agar plates after 28 days of incubation based on morphological observations. Of these 68 isolates, only 22 isolates showed potential antibacterial activities against at least one bacterial isolate using perpendicular streak method. These bacterial isolates were grouped as Gram positive cell wall with rod morphology (Table 1).

Table 1. List of isolates that displayed inhibition against at least one bacterial indicator strains with their morphological characteristic. An initial code indicated the dominant mangrove plant species where soil sample was collected namely SA (Sonneratia alba), AM (Avicenna marina), RA (Rhizopora apiculata), RM (Rhizopora mucronata).

\begin{tabular}{|c|c|c|c|c|c|c|}
\hline \multirow{2}{*}{ Isolate } & \multirow{2}{*}{ Morphology } & \multirow{2}{*}{ Gram staining } & \multicolumn{4}{|c|}{ Distance against bacterial indicator strains (mm) } \\
\hline & & & E. coli & K. pneumoniae & S. aureus & S. mutans \\
\hline SA1 & rod & positive & no activity & no activity & no activity & 7 \\
\hline SA3 & rod & positive & 2 & 2 & 2 & 2 \\
\hline SA4 & rod & positive & 15 & 10 & 20 & 15 \\
\hline SA9 & rod & positive & no activity & no activity & 5 & no activity \\
\hline SA11 & rod & positive & no activity & no activity & no activity & 3 \\
\hline SA14 & rod & positive & no activity & no activity & 5 & no activity \\
\hline AM1 & rod & positive & no activity & 4 & no activity & no activity \\
\hline AM3 & rod & positive & 2 & 2 & 2 & 3 \\
\hline AM4 & rod & positive & no activity & no activity & 2 & no activity \\
\hline AM8 & rod & positive & no activity & 2 & no activity & no activity \\
\hline AM9 & rod & positive & no activity & no activity & no activity & 3 \\
\hline AM12 & rod & positive & no activity & 4 & no activity & 4 \\
\hline AM13 & rod & positive & no activity & 4 & no activity & no activity \\
\hline AM20 & rod & positive & no activity & 3 & 3 & 2 \\
\hline $\mathrm{AM} 23$ & rod & positive & no activity & 4 & 3 & 5 \\
\hline AM30 & rod & positive & no activity & 3 & 3 & 2 \\
\hline RA1 & rod & positive & 2 & 1 & 5 & no activity \\
\hline RM2 & rod & positive & no activity & no activity & 5 & no activity \\
\hline RM3 & rod & positive & no activity & 5 & no activity & no activity \\
\hline RM9 & rod & positive & no activity & no activity & no activity & 5 \\
\hline RM10 & rod & positive & 6 & no activity & 8 & 7 \\
\hline RM18 & rod & positive & 4 & 5 & 3 & 5 \\
\hline
\end{tabular}

The level of antibacterial inhibition varied among the 22 bacterial isolates. In general majority of isolates weakly inhibited at least one indicator bacterium. Two isolates (SA1 and RM10) displayed moderate antibacterial activity. SA4, however, is the only bacterial isolates with the strongest antibacterial potential against all the four bacterial indicator (Figure 3).

Perpendicular streak was selected as the prescreening method because the approach is rather straight forward and has been applied effectively to determine isolates with antibacterial activities (Boontanom and Chantasari, 2020; Balouiri et al., 2016). It could be assumed that isolate SA4 could potentially synthesis active antibacterial molecules based on substantial distance formed between the isolate and bacterial indicators. Antibacterial substances produced by an active bacterial isolate were diffused on agar media so that growth of other bacteria was inhibited (Balouiri et al., 2016). Nucleotide sequences comparison of isolate SA4 against NCBI blast database indicated that the top hit was assigned as Bacillus subtilis strain BIL/BS-168 with 97,36\% identity. Bacillus subtilis in general has been regarded for its ability to produce antimicrobial compounds and has been applied for food preservation and crop protection (Caulier et al., 2019). For example, bacteriocin is one example of an active compound 
responsible for antimicrobial activities in B. subtilis (Sharma et al., 2018).

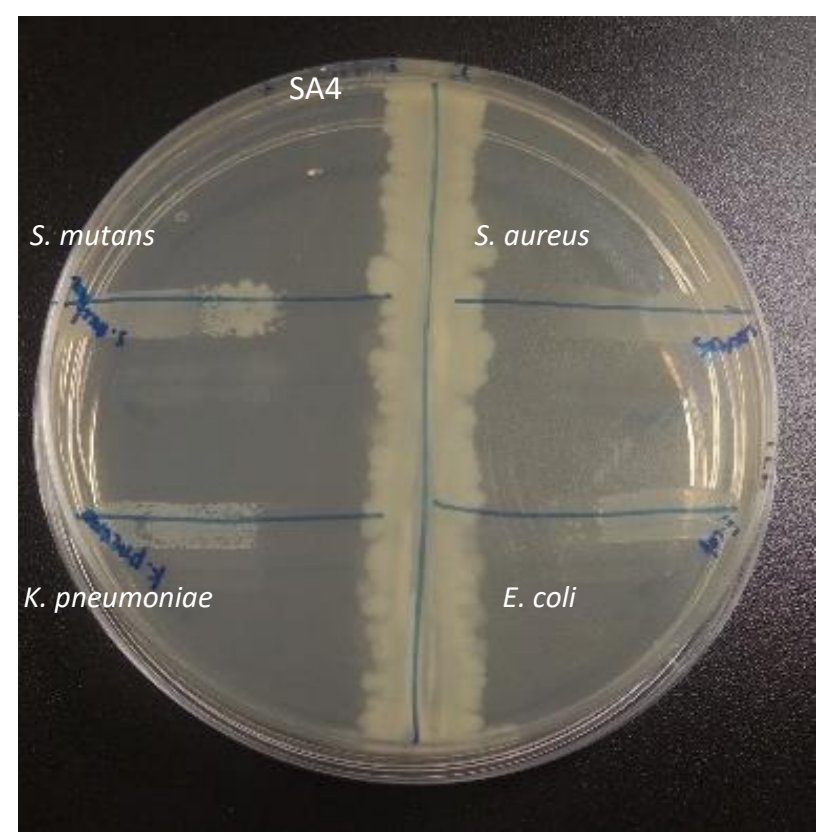

Figure 3. Perpendicular streak of isolate SA4 against Gram positive and negative bacteria. A clear distance of $\geq 10 \mathrm{~mm}$ between each bacterial indicator and the isolate SA4 indicated strong antibacterial properties synthesized by the bacteria.

However, at this stage it is still unknown what type of antibacterial substances that could be produced by the SA4 isolate. Further research, therefore should be focused to identify type of antibacterial compounds synthesized by the SA4 isolate. In addition, genetic analysis should also be done to analyze metabolic pathways that are responsible to synthesize antibacterial compounds in the SA4 isolate. Despite, the remaining 21 bacterial isolates only showed weak to moderate antibacterial activities based on perpendicular streak do not automatically exclude the full potential of these isolates. It could be that each isolate requires different time to accumulate their antibacterial substances. Therefore, a liquid fermentation followed by organic extraction of these isolates using different solvents depending on polarity of the expected compounds should be done to fully unravel the true antibacterial potential or other therapeutic capability.

\section{CONCLUSION}

In conclusion, this study obtained 22 bacterial isolates with antibacterial potential from mangrove soil of the Ngurah Rai mangrove forest. All of these isolates were characterized by rod shape and Gram-positive cell wall under microscope observation. Isolate SA4 displayed the strongest antibacterial potential based on the perpendicular streak method with clear distance zone above $10 \mathrm{~mm}$. Isolate $\mathrm{SA} 4$ was closely related to Bacillus subtilis strain BIL/BS-168with $97.36 \%$ sequence identity based on 16S rRNA gene sequences. Further studies should be focused to extrapolate the antibacterial potential of these 22 isolates especially the isolate SA4 by performing organic extractions and screening against different bacterial pathogen. Apart from antibacterial activities, other therapeutic potential of the obtained isolates should also be explored such as antifungal, antioxidant, or anticancer in order to fully unravel the biological capabilities of these isolates.

Acknowledgements: This research was fully funded by the Research and Community Development Unit (Unit Penelitian dan Pengabdian Masyarakat) Faculty of Medicine and Health Sciences, Warmadewa University under grant no. 417/Unwar/FKIK/UP2M/KP02/VII/2019. We would also thank Ir. Magdalena Hehakaya, M.Si from the Department Environment and Forestry Bali Province for her guidance during the sampling trip at the Ngurah Rai Mangrove Forest.

Conflicts of Interest: The authors declare that there are no conflicts of interest.

\section{REFERENCES}

Assis, D. A., Rezende, R. P., \& Dias, J. C. (2014). Use of Metagenomics and Isolation of Actinobacteria in Brazil's Atlantic Rainforest Soil for Antimicrobial Prospecting. ISRN Biotechnol, 2014, 909601. doi:10.1155/2014/909601

Azman, A. S., Othman, I., Velu, S. S., Chan, K. G., \& Lee, L. H. (2015). Mangrove rare actinobacteria: taxonomy, natural compound, and discovery of bioactivity. Front Microbiol, 6, 856. doi:10.3389/fmicb.2015.00856

Balai Pemantapan Kawasan Hutan Wilayah VIII Denpasar. (2018). Potensi Wisata Taman Hutan Raya Ngurah Rai Provinsi Bali. In. http://bpkh8.menlhk.go.id/pdf/karya_tulis_mandiri/liflet_tahu ra.pdf.

Balouiri, M., Sadiki, M., \& Ibnsouda, S. K. (2016). Methods for in vitro evaluating antimicrobial activity: A review. Journal of $\begin{array}{llll}\text { Pharmaceutical } \quad \text { Analysis, } & \text { 6(2), }\end{array}$ doi:https://doi.org/10.1016/j.jpha.2015.11.005

Bentley, S. D., Chater, K. F., Cerdeno-Tarraga, A. M., Challis, G. L., Thomson, N. R., James, K. D., . . . Hopwood, D. A. (2002). Complete genome sequence of the model actinomycete Streptomyces coelicolor A3(2). Nature, 417(6885), 141-147. doi:10.1038/417141a

Boontanom, P., \& Chantasari, A. (2020). Diversity of culturable epiphytic bacteria isolated from seagrass (Halodule uninervis) in Thailand and their preliminary antibacterial activity. Biodiversitas,

21(7). doi:https://doi.org/10.13057/biodiv/d210706

Booth, J. (2018). Ecology of Mangrove Microbiome. (PhD). King Abdulah University of Science and Technology,

Caulier, S., Nannan, C., Gillis, A., Licciardi, F., Bragard, C., \& Mahillon, J. (2019). Overview of the Antimicrobial 
Compounds Produced by Members of the Bacillus subtilis Group. Frontiers in Microbiology, 10(302). doi:10.3389/fmicb.2019.00302

Centers for Disease Control and Prevention. (2018). Antibiotic Resistance: A Global Threat. Retrieved from Atlanta:

Cheng, G., Dai, M., Ahmed, S., Hao, H., Wang, X., \& Yuan, Z. (2016). Antimicrobial Drugs in Fighting against Antimicrobial Resistance. Front Microbiol, 7, 470. doi:10.3389/fmicb.2016.00470

Debbab, A., Aly, A. H., Lin, W. H., \& Proksch, P. (2010). Bioactive compounds from marine bacteria and fungi. Microb Biotechnol, 3(5), 544-563. doi:10.1111/j.17517915.2010.00179.x

Elbendary, A. A., Hessain, A. M., El-Hariri, M. D., Seida, A. A., Moussa, I. M., Mubarak, A. S., . . . El Jakee, J. K. (2018). Isolation of antimicrobial producing Actinobacteria from soil samples. Saudi $J$ Biol Sci, 25(1), 44-46. doi:10.1016/j.sjbs.2017.05.003

Friess, D. A. (2016). Mangrove forests. Curr Biol, 26(16), R746748. doi:10.1016/j.cub.2016.04.004

Jiang, Z. K., Tuo, L., Huang, D. L., Osterman, I. A., Tyurin, A. P., Liu, S. W., . . . Sun, C. H. (2018). Diversity, Novelty, and Antimicrobial Activity of Endophytic Actinobacteria From Mangrove Plants in Beilun Estuary National Nature Reserve of Guangxi, China. Front Microbiol, 9, 868. doi:10.3389/fmicb.2018.00868

Lane, D. J. (1991). 16S/23S rRNA Sequencing (E. Stackebrandt \& M. Goodfellow (eds.); Nucleic Ac. John Wiley and Sons, pp. 115-175.

Lee, L. H., Zainal, N., Azman, A. S., Eng, S. K., Goh, B. H., Yin, W. F., . . . Chan, K. G. (2014). Diversity and antimicrobial activities of actinobacteria isolated from tropical mangrove sediments in Malaysia. ScientificWorldJournal, 2014, 698178. doi:10.1155/2014/698178
Mohamed, H., Miloud, B., Zohra, F., Garcia-Arenzana, J. M., Veloso, A., \& Rodriguez-Couto, S. (2017). Isolation and Characterization of Actinobacteria from Algerian Sahara Soils with Antimicrobial Activities. Int J Mol Cell Med, 6(2), 109120. doi:10.22088/acadpub.BUMS.6.2.5

Munita, J. M., \& Arias, C. A. (2016). Mechanisms of Antibiotic Resistance. Microbiol Spectr, 4(2). doi:10.1128/microbiolspec.VMBF-0016-2015

Roca, I., Akova, M., Baquero, F., Carlet, J., Cavaleri, M., Coenen, S., . . . Vila, J. (2015). The global threat of antimicrobial resistance: science for intervention. New Microbes New Infect, 6, 22-29. doi:10.1016/j.nmni.2015.02.007

Sharma, G., Dang, S., Gupta, S., \& Gabrani, R. (2018). Antibacterial Activity, Cytotoxicity, and the Mechanism of Action of Bacteriocin from Bacillus subtilis GAS101. Med Princ Pract, 27(2), 186-192. doi:10.1159/000487306

Singh, V., Haque, S., Singh, H., Verma, J., Vibha, K., Singh, R., . . . Tripathi, C. K. (2016). Isolation, Screening, and Identification of Novel Isolates of Actinomycetes from India for Antimicrobial Applications. Front Microbiol, 7, 1921. doi:10.3389/fmicb.2016.01921

van der Heul, H. U., Bilyk, B. L., McDowall, K. J., Seipke, R. F., \& van Wezel, G. P. (2018). Regulation of antibiotic production in Actinobacteria: new perspectives from the postgenomic era. Nat Prod Rep, 35(6), 575-604. doi:10.1039/c8np00012c

Ventola, C. L. (2015). The antibiotic resistance crisis: part 1: causes and threats. $P \& T:$ a peer-reviewed journal for formulary management, 40(4), 277-283. Retrieved from https://www.ncbi.nlm.nih.gov/pubmed/25859123 https://www.ncbi.nlm.nih.gov/pmc/articles/PMC4378521/

World Health Organization. (2018). Antibiotic Resistance. Retrieved from Geneva: https://www.who.int/news-room/factsheets/detail/antibiotic-resistance 
THIS PAGE INTENTIONALLY LEFT BLANK 